\title{
The Factor Analysis of Organizational Commitment, Job Satisfaction and Performance among Lecturers in Batam
}

\author{
Hazriyanto ${ }^{1}$, Badaruddin Ibrahim ${ }^{2 *}$ \\ ${ }^{1}$ STIE Galileo, Batam City, Riau Islands, INDONESIA \\ ${ }^{2}$ Faculty of Technical and Vocational Education, Universiti Tun Hussein Onn Malaysia, 86400 Batu Pahat, Johor, \\ MALAYSIA
}

DOI: https://doi.org/10.30880/jtet.2019.11.01.019

Received $21^{\text {st }}$ August 2018; Accepted $31^{\text {st }}$ October 2018; Available online $31^{\text {st }}$ March 2019

\begin{abstract}
This article intended to determine the important elements in commitment, satisfaction and job performance of university lecturers. This study involved 179 respondents from 3 universities located in Batam, Indonesia. The survey instrument had used a 5-point Likert scale to obtain feedback. Overall, the survey had achieved a very high level of reliability for organizational commitment, job satisfaction, and job performance. The data obtained was processed using exploratory factor analysis (EFA) to examine the structure of commitment, satisfaction, and performance factors. Overall, the instrument, which was the questionnaire, was valid. It was found, based on the EFA, that the three important factors were commitment, satisfaction, and performance. Hence, how could the findings significantly solve the problem statement as well as state the vision and potential of future studies. The Rotated Component Matrix showed the correlation between items and the factors after the Varimax rotation. Factor 1 contained 13 items, Factor 2 contained 12 items, while Factor 3 contained 11 items. It was found that items in Factor 1 could be under the "Commitment Factor", items in Factor 2 could be under the "Performance Factor", while items under factor 3 could be under the "Satisfaction Factor". The outcome of this study could act as a guideline for lecturers to excel in their careers as well as assist institutions to develop effective evaluations.
\end{abstract}

Keywords: Exploratory factor analysis; organizational commitment; job satisfaction; performance; lecturer

\section{Introduction}

Educational problems faced by the university are related to the need to enhance the performance of university lecturers. Various efforts have been implemented by universities to improve the quality of education in efforts to support the excellent achievement of the university, which would then reflect the performance of the university lecturers (Suwanda, 2018). Enhancing job satisfaction among lecturers, developing commitment and improving performance has gained importance. This is related to job performance and also contributes towards the lecturer's achievements in job performance such as training, rewards, emoluments, discipline as well as various facilities for teaching and learning (Fatuma Mussa, 2017).

It is hoped that university lecturers would be able to enhance quality and independently solve problems and face challenges, especially those related to performance achievement (either individually or in a group) and when implementing tasks or responsibilities. According to Siagian (2013), job satisfaction is a negative and positive perspective of someone associated with the job. Performance is the work product obtained by the employee, a management process or an organization, in which the work product is explicitly in the form of quality or quantity (Sedarmayanti, 2011). Work satisfaction is one factor that contributes towards enhancing the achievement of a lecturer's job performance as well as commitment. An employee of an organization who obtains job satisfaction is 
inclined to possess a higher level of performance compared to an organization that has employees who face less job satisfaction (Robbins, 2006). Meanwhile, organizational commitment is how capable is an individual in identifying his/her capability and getting involved in an organization (Spector, et al., 2000). Job satisfaction is inclined to have an effect on employee's performance, whereby an organization that has employees with a high level of job satisfaction are inclined to possess a higher performance level compared to organizations who have employees who are less satisfied with their jobs (Robbins, 2006).

A study by McCausland et al., (2005) showed that job satisfaction could enhance employee performance and the performance provides a positive influence towards job satisfaction. Besides that, a high level of employee commitment can enhance quality-based employee productivity (Wibowo, 2011). In addition, Anari (2012) found a significant relationship between job satisfaction and organizational commitment... Besides that, there is a lack of studies concerning commitment, job satisfaction and performance of university lecturers, especially in Batam Province in the Riau Islands of Indonesia. This study aimed to identify the problems related to items such as job commitment, job satisfaction and job performance. The focus of this study is to determine the items for each factor related to commitment, job satisfaction and job performance.

There are reports regarding commitment, job satisfaction and performance of lecturers and their support for the university. This often occurs to lecturers and to those who are busy with management and office tasks. Chamundeswari (2013), Mangi, Soomro, Ghumro, Abidi, \& Jalbani (2011) recommended the evaluation of commitment, job satisfaction, and performance of lecturers in order to meet their needs effectively. A variety of evaluation processes produce the best results. This variety involves investment in time and effort in formulating research objectives, and finally increase the input during the eventual preparation of the report.

The purpose of this study was to identify and describe the factors that contribute to commitment, job satisfaction, and performance of lecturers in Batam city. The study will also identify the factors that were developed by the Exploratory Factor Analysis.

\section{2. $\quad$ Research Methods}

This study had used the survey instrument to measure commitment, satisfaction and job performance among university lecturers in Batam. The population for this study comprised lecturers from 3 universities. The target respondents were university lecturers from the universities in Batam. The data used in this study were the current data obtained from the 3 universities, namely Putera Batam University, Batam University, Riau Kepulauan University. A total of 179 lecturers had filled up the questionnaire that was distributed.

Table 1 - Descriptive Demographic Respondents

\begin{tabular}{clccc}
\hline No & & Gender & Frequency & Percentage \\
\hline 1 & Men & 91 & 50.8 \\
2 & Female & 88 & 49.2 \\
& Total & 179 & 100 \\
\hline
\end{tabular}

The result of the analysis presented in Table 1 can be identified that male respondents involved in the study a total of 91 people $(50.8 \%)$ and female respondents found little more than male respondents, namely $49.2 \%$ or a total of 88 people with total respondents 179 respondents. The questionnaires used were related to commitment, satisfaction and performance and contained 46 items.

There are 25 performance indicators, 15 job satisfaction indicators, and 9 organizational commitment indicators. The items used in this study were adapted from numerous studies, such as Locke (1976), Mowdey et al., (1979), Timpe (1992), Hersey, Blanchard, and Johnson (1996), Monday, et. al., (1996), Gibson et., al., (1996), Ravianto (1988), Armstrong and Baron (1998), Prawirosentono (1999), Robbins (2001), Kreitner and Kinicki (2001), Gomes and Larsen (2002), George \& Jones (2002), Mellor et., al., (2003), Syamsuddin (2006), Mitcell (Bachari, 2007), Pasolong (2008), Robbins (2008), Dikti (2010), Rivai (2011), Job Descriptive Index (JDI), Sejjaaka \& Kaawaase (2014).

All the data used in this study were analysed using mean, standard deviation and frequency. The method of analysis used in this study was the reliability and descriptive analyses. Next, the exploratory factor analysis (EFA) was carried out on the items in this study. The exploratory factor analysis (EFA) was intended to determine how the items used were classified according to certain structural factors (Hair et al. 2010). 
Table 2 - Indicators of Commitment, Job Satisfaction, and

Performance

\begin{tabular}{|l|l|l|}
\hline \multicolumn{1}{|c|}{ Commitment } & \multicolumn{1}{|c|}{ Job Satisfaction } & \multicolumn{1}{c|}{ Performance } \\
\hline Have strong beliefs & The Work is mentally & Potential partners \\
against University & challenged & Communication skills \\
Have confidence in the & Appropriate & The ability to convey the idea in meeting \\
goals of the University & Remuneration & Ability to handle works \\
Have the feeling the & Working Environment & The system of work and facilities rendered organization \\
emotional with the & that supports & Leadership \\
University & Supportive co-workers & Acknowledgements \\
Have confidence in the & Personality & Division of roles \\
values appearing in the & Salaries & The perception of reward and satisfaction \\
University & Related work & Clarity of purpose and security \\
Benefit financially when & Monitoring & Expectations of appreciation \\
remain in University & Organization and & Encourage \\
The production or & management & The desire to succeed \\
financial resources are & Work on the right place & Standard operating procedures \\
distracted when leaving & Different people in & Time Standard \\
University & employment & Standard Productivity \\
Have an obligation to & Need fulfilment & Quality standards \\
remain in his position at & Discrepancies & Standards of conduct \\
the University & Value attainment & Individual Commitment \\
Have a good relationship & Dispositional & The personality Competency \\
with the University & & The quality of encouragement and guidance of the leaders \\
Have appropriate moral & & Support do managers and team leaders \\
and ethics with in & & High stress levels and changes in the internal and external \\
University & environment \\
& & The type of work \\
& & The perception of the task \\
\hline
\end{tabular}

\section{Results and Discussion}

The results of the descriptive analysis on commitment, satisfaction and performance shown in Table 3 indicates that the mean score variable is at a good level.

Table 3 - Descriptive Statistics

\begin{tabular}{|c|c|c|c|}
\hline No & Variable & Mean & Standard Deviation \\
\hline 1 & Commitment & 3.71 & 0.86 \\
\hline 2 & Satisfaction & 3.68 & 0.87 \\
\hline 3 & Performance & 4.01 & 0.77 \\
\hline
\end{tabular}

The results of the reliability test show that the Cronbach's Alpha value for the organizational commitment items is (0.902) and at a high level. The reliability value for job satisfaction items is $(0.875)$ and at a high level. The reliability value for items related to job performance was $(0.886)$ and was at a high level. It could be concluded that the values of the items in the survey regarding organizational commitment, job satisfaction and job performance were reliable (Bryman and Cramer, 1990; Aiken and West, 1991; Sekaran, 1992; Konting, 2003; Ghozali, 2004).

The Bartlett's Test of Sphericity was used to determine whether the correlation between the items was adequate to carry out the factor analysis. The results of the test were significant at $\mathrm{p}<.05(.000<.05)$, which shows that the items were adequate for the factor analysis. The KMO test indicates multicollinearity. If two or more items have the same correlation value, them the items measure the same aspect. The KMO test helps to identify the suitability of the items for the factor analysis. The factor analysis is suitable if the KMO value is bigger than .50. As in Table 2, the KMO value for this case shows that the data has no serious problems of multicollinearity; hence, the items are suitable for the factor analysis.

Table 4 - KMO and Bartlett's

\section{Test KMO and Bartlett's \\ Test}

\begin{tabular}{|c|c|c|}
\hline \multicolumn{2}{|c|}{ Kaiser-Meyer-Olkin Measure of Sampling Adequacy. } & .857 \\
\hline \multirow[t]{3}{*}{ Bartlett's Test of Sphericity } & Approx. Chi-Square & 4868.151 \\
\hline & df & 1035 \\
\hline & Sig ............. & .000 \\
\hline
\end{tabular}


Table 5 - Total Variance Explained

\begin{tabular}{|c|c|c|c|c|c|c|c|c|c|}
\hline \multirow{2}{*}{ Component } & \multicolumn{3}{|c|}{ Initial Eigenvalues } & \multicolumn{3}{|c|}{$\begin{array}{l}\text { Extraction Sums of Squared } \\
\text { Loadings }\end{array}$} & \multicolumn{3}{|c|}{$\begin{array}{c}\text { Rotation Sums of Squared } \\
\text { Loadings }\end{array}$} \\
\hline & Total & $\begin{array}{c}\% \text { of } \\
\text { Variance }\end{array}$ & $\begin{array}{c}\text { Cumulative } \\
\%\end{array}$ & Total & $\begin{array}{c}\% \text { of } \\
\text { Variance }\end{array}$ & $\underset{\%}{\text { Cumulative }}$ & Total & $\begin{array}{c}\% \text { of } \\
\text { Variance }\end{array}$ & $\begin{array}{c}\text { Cumulative } \\
\%\end{array}$ \\
\hline 1 & 12.844 & 27.922 & 27.922 & 12.844 & 27.922 & 27.922 & 5.734 & 12.466 & 12.466 \\
\hline 2 & 5.188 & 11.278 & 39.199 & 5.188 & 11.278 & 39.199 & 5.394 & 11.726 & 24.192 \\
\hline 3 & 2.5 & 5.434 & 44.633 & 2.5 & 5.434 & 44.633 & 4.133 & 8.985 & 33.177 \\
\hline 4 & 2.159 & 4.694 & 49.327 & 2.159 & 4.694 & 49.327 & 3.691 & 8.024 & 41.201 \\
\hline 5 & 1.716 & 3.73 & 53.058 & 1.716 & 3.73 & 53.058 & 2.764 & 6.009 & 47.209 \\
\hline 6 & 1.424 & 3.095 & 56.153 & 1.424 & 3.095 & 56.153 & 2.321 & 5.046 & 52.255 \\
\hline 7 & 1.406 & 3.058 & 59.21 & 1.406 & 3.058 & 59.21 & 2.213 & 4.811 & 57.066 \\
\hline 8 & 1.255 & 2.728 & 61.939 & 1.255 & 2.728 & 61.939 & 1.976 & 4.296 & 61.361 \\
\hline 9 & 1.111 & 2.416 & 64.355 & 1.111 & 2.416 & 64.355 & 1.377 & 2.993 & 64.355 \\
\hline
\end{tabular}

There were 9 components (factors) that had an Eigenvalue of greater than 1, as shown in Table 5. These nine factors contributed to 64.35 percent changes to the overall variance (job performance). There were 37 other components that only contributed to 35.65 percent of the dependent variable's variance. However, only 3 factors shown below contributed to a variance that was more than 5 percent, which were component 1 ( 27.92 percent), component 2 (11.28 percent) and component 3 (5.43 percent). When observing the percentage of variance for the rotation loading value, three main factors contributed more than 8.98 percent. Since the contribution of the fourth factor and the rest were near the three factors, the researcher needs to examine the Scree Plot graph to ensure that the number of extracted main factors are the main actors shown in Diagram.

The Scree plot graph clearly shows that there are three main factors that have immensely contributed to the overall change in variance in the dependent variable (lecturer's job performance achievement).

The rotated component matrix shows the correlation between the items and its factors after the varimax rotation. Items in Factor 1 "Commitment" contained 13 items (items K1 to K9 and KK1, KK2 and KK5). Items in Factor 2 "Job Performance" contained 12 items (items PK4, PK 12 to PK 15 and PK 18 to PK 22), while items in Factor 3 "Job Satisfaction" contained 11 items (items KK 4 to KK 8 and KK10 to KK15).

Component Transformation Matrix in table 7 shows that the correlation between the three factors are weak, which was below 0.50 (the accepted strength of correlation should be between .097 and .465). Hence, all three factors are free from one another, which indicates they are independent constructs. The survey suggested that "Job performance", which contains 46 items, should be analysed using factor analysis. The Eigenvalues and Scree Plot graph shows that the questionnaire items contain more than one factor.

According to this result, the researcher rejected the null hypothesis and decided that the items in the questionnaire were non-unidimensional, as it contained more than one construct. Through the Varimax rotation, the Rotated Component Matrix table shows that the items in the questionnaire formed three dimensions (contains 3 factors). Hence, the three factors were extracted from the suggested survey.

All three factors predicted a 33.18 percent overall variance for the dependent variable "job performance" (Factor $1=12.47$ percent; Factor $2=11.73$ percent; Factor $3=8.99$ percent). The factor analysis also showed that the correlation between all three factors was less that .50 (the $\mathrm{r}$ value was between .09 to .46). This means that all three factors are free and independent of one another. In other words, all three factors are separate constructs.

An examination of items in each factor by referring to previous studies has items in Factor 1 under the "Commitment construct", items in Factor 2 under "Job Performance", while items in Factor 3 under the "Job Satisfaction" construct.

The results of the analysis show that there are six items with various concepts that could be loaded into two factors. Upon examination, the contents of all six items were found to be suitable with the aim this study. Thus, if the aim of this study is to differentiate these three constructs, then the six items should be discarded because an item cannot represent two constructs in a comparative analysis between constructs. The findings show a positive relationship between development, training and job satisfaction with the achievements of workers. Exercises and development will bring to the stage a higher job satisfaction in the accomplices and they will fulfil their tasks with a lot of responsibility with the best offerings (Osama, Haseeb, Waseem, Ayaz, \& Ijaz, 2016). Similarly, Anwar (2015) found that job satisfaction and organizational commitment have a positive influence on the lecturer's achievements. 
Table 6 - Rotated Component Matrix ${ }^{a}$

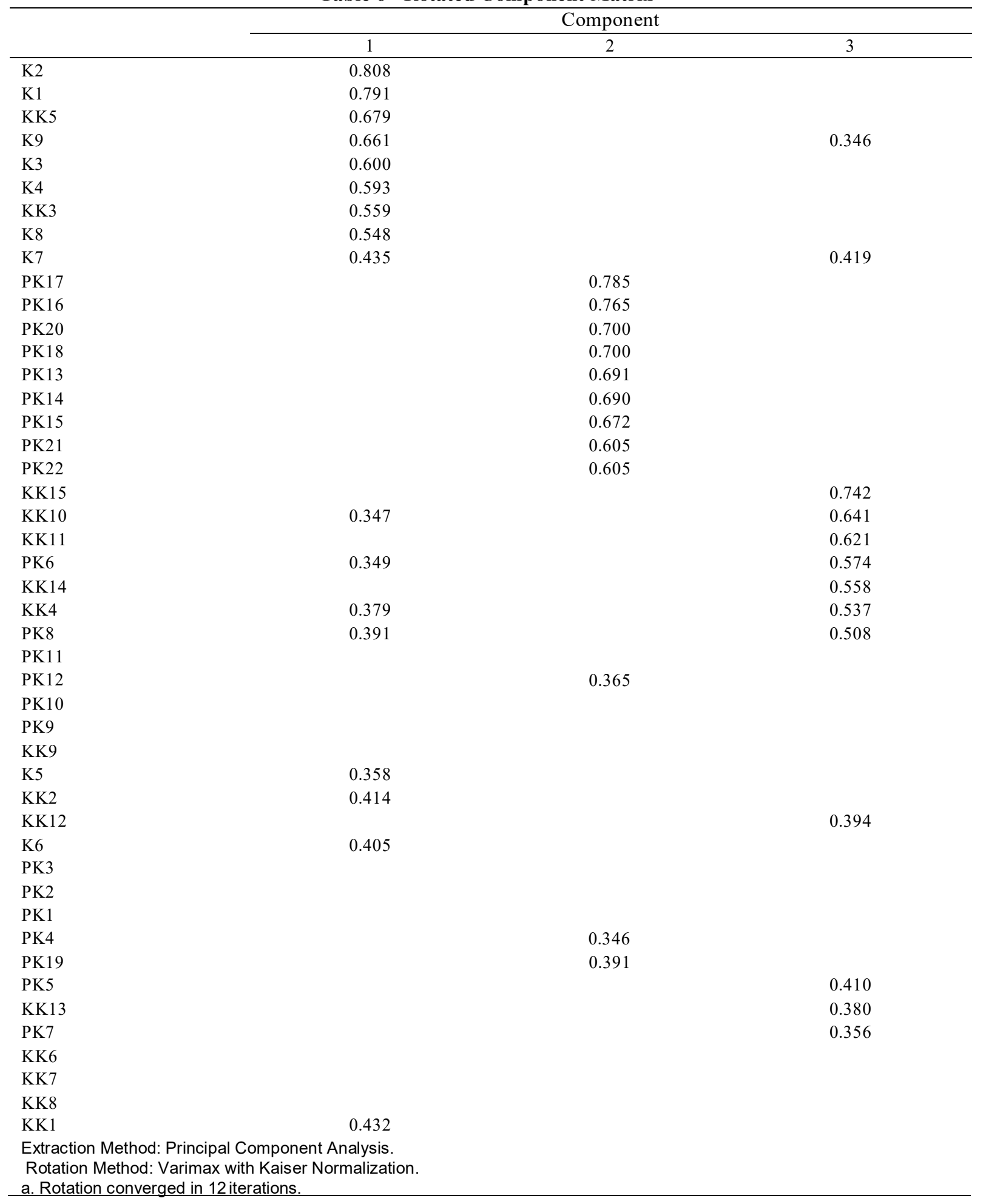

Table 7 - Component Transformation Matrix

\begin{tabular}{cccc}
\hline Component & 1 & 2 & 3 \\
\hline 1 & 0.55 & 0.411 & 0.439 \\
2 & -0.399 & 0.69 & -0.277 \\
3 & 0.097 & 0.465 & 0.123
\end{tabular}

Extraction Method: Principal Component Analysis.

Rotation Method: Varimax with Kaiser Normalization. 


\section{Conclusion}

Therefore, by examining the characteristics of each item in each factor in reference to past studies, it was found that items in Factor 1 could be placed under the "commitment" construct (comprising 13 items, namely Commitment 1 to Commitment13), items in Factor 2 could be placed under the "performance" construct (comprising 12 items, namely Performance1, to Performance12) and items in Factor 3 could be placed under the "satisfaction" construct (comprising 11 items, namely Satisfaction1 to Satisfaction 11). Based on the factor analysis, items in the questionnaire (consisting of 36 items) were arranged according to the confined constructs.

This study revealed that there are ways to develop an effective evaluation, which involves aspects such as commitment, job satisfaction and performance. However, a lecturer might possess different levels of each aspect. This study has shown that commitment, job satisfaction, and performance are contributing factors to the performance of lecturers. The outcome of this study could act as a guideline for lecturers to excel in their careers as well as assist institutions to develop effective evaluations.

It was suggested that future studies use the CFA analysis to certify each item so that it is placed according to correct factor. CFA is used to test the unidimensional of dimensions, which explains the latent variable in a model. In addition, all indicators adopted in this study had helped to form the related variables (Rasmen, 2008). The Confirmatory Factor Analysis (CFA) was used to test a measurement model to determine whether current indicators could explain a construct in a more detailed fashion (Santoso, 2014). The acquired loose studies showed a positive relationship between job satisfaction and workers' achievements. Hence, when higher job satisfaction in accomplished employees can fulfil their tasks with a lot more responsibility (Osama, Haseeb, Waseem, Ayaz, \& Ijaz, 2016).

\section{Acknowledgement}

The authors would like to thank the Research Management Centre, Universiti Tun Hussein Onn Malaysia (UTHM) for their support in making this project possible. Part of this work was supported by the Research University Grant initiated by UTHM.

\section{References}

Aiken, L. S., \& West, S. G. (1991). Multiple regression: Testing and interpreting interactions. Newbury Park: Sage.

Anari, N. N. (2012). Teachers: emotional intelligence, job satisfaction, and organizational commitment. Journal of Workplace Learning,24(4). https://doi.org/10.1108/13665621211223379

Anwar, A. A. (2015). The Effects of Leadership Styles, Organizational Climate, Environmental Aspects and Organizational Commitment and Job Satisfaction on the Lectures' Performance of Kopertis III in Jakarta Haris Maupa. Scientific Research Journal, 3(9), 2201-2796. Retrieved from www.scirj.org

Armstrong, Michael \& Angela Baron. (1998). Performance Management. London: Institute of Personnel and Development.

Bryman, A., \& Cramer, D. (1990). Quantitative Data Analysis for Social Scientists. London: Routledge

Chamundeswari, S. (2013). Job satisfaction and performance of school teachers. International Journal of Academic Research in Business and Social Sciences, 3(5), 420-428.

David J. Mellor et al. (2003). How can managers reduce employee intention to quit? Journal of Managerial Psychology Vol. 19 No. 2, pp. 170-187

Fatuma Mussa, (2017). An Assessment of Post Training Employee Performance In Higher Learning Institutions In Tanzania: Acase Of Ardhi University. Mzumbe University

George, J.M., \& Jones, G.R. (2002). Understanding \& Managing Organizational Behavior, $3^{\text {rd }}$ ed. New Jersey: Pearson Education Inc.

Ghozali, I. (2004). Aplikasi analisis multivariate dengan program SPSS. Semarang: Badan Penerbit Universitas Diponegoro.

Gibson, Ivancevich, Donnelly. (1996). Organisasi, Perilaku, Struktur, Prosa-Prosa, (Alih Bahasa Nunuk Adiarni). Jakarta: Penerbit Binarupa Aksara.

Gomes, Faustino Cardoso. (2002). Manajemen Sumber Daya Manusia. Yogyakarta: Andi.

Hair, J. F. Jr, R.E., Anderson, R. L., Tatham. \& W.C. Black. (1998). Multivariate data analysis. New Jersey: Prentice Hall Inc. 
Hersey, Paul \& Kenneth H. Blanchard. (1996). Manajemen Perilaku Organisasi: Pendayagunaan Sumber Daya Manusia. Edisi Keempat. Alih Bahasa: Agus Dharma. Jakarta: Erlangga

K. Sejjaaka, S., \& K. Kaawaase, T. (2014). Professionalism, rewards, job satisfaction and organizational commitment amongst accounting professionals in Uganda. Journal of Accounting in Emerging Economies, 4(2), 134-157. https://doi.org/10.1108/JAEE-01-2012-0003

Kreitner, Robert \& Angelo, Kinicki. (2001). Organizational Behavior. New York: Addison-Wesley Publishing Company, Inc.

Locke, E. A. (1976). The Nature and Cause of Job Satisfaction. In M. D. Dunnette (Ed). Handbook of Industrial and Organization Psychology (Chicago: Rand McNally).

Mangi, R. A., Soomro, H. J., Ghumro, I. A., Abidi, A. R., \& Jalbani, A. A. (2011). A Study of Job Satisfaction Among Non Phd Faculty in, 1(7), 83-90.

Mohd Majid Konting. (2004). Kaedah Penyelidikan Pendidikan. Kuala Lumpur: Dewan Bahasa dan Pustaka.

Monday, R. Wayne., \& Noe, Robert M. (1996). Human Resource Management. Prentice Hall, Inc. Upper Saddle River, New Jersey.

Mowday, R. T., Steers, R. M., \& Porter, L. W. (1979). “The measurement of organizational commitment”, Journal of Vocational Behaviour, 14, 224-247.

Osama, S., Haseeb, B., Waseem, R. M., Ayaz, M., \& Ijaz, M. (2016). Impact of Training and Development of Employees on Employee Performance through Job Satisfaction : A Study of Telecom Sector of Pakistan, 7(1), 29-46. https://doi.org/10.5296/bms.v7i1.9024

Pasolong, Harbani. (2008). Kepemimpinan Birokrasi. Bandung: Alfabeta.

Prawirosentono.S. (1999). Kebijakan Kinerja Karyawan. Edisi Pertama. Yogyakarta: BPFE.

Rasmen, A. N. (2008). Mudah dan Cepat Mengoperasikan AMOS 16.0 Untuk Analisis SEM (Structural Equation Modeling). Denpasar Bali: Universitas Pendidikan Nasional.

Ravianto. (1988). Produktivitas dan Manusia Indonesia. Jakarta: SIUP

Robbins, P.Stephen. (2001). Perilaku Organisasi: Konsep, Kontroversi, dan Aplikasi. Alih bahasa Handayana Pujaatmika. Edisi Bahasa Indonesia. Jakarta: Prenhalindo.

Robbins, S. P., \& Judge, T. A. (2008). Perilaku Organisasi. (2nd ed.). Jakarta: Salemba Empat

Robbins, Stephen P. (2006). Perilaku Organisasi. Edisi kesepuluh. Jakarta: PT Indeks Kelompok Gramedia

Santoso, S. (2010). Statistik Multivariat. Jakarta: PT Elex Media Komputindo.

Sedarmayanti, (2011). Manajemen Sumber Daya Manusia, Reformasi Birokrasi dan Manajemen Pegawai Negeri Sipil (Cetakan Kelima). Bandung: PT Refika Aditama

Siagian, Sondang, 2013, Manajemen Sumber Daya Manusia, Bumi Aksara, Jakarta

Spector, Paul E., et al. (2000). Industrial and Organizational Psychology: Research and Practise; Inc. USA.

Stephen P. Robbins - Timothy A. Judge. (2008). Perilaku Organisasi, Buku 1 Edisi 12. Jakarta: Salemba Empat.

Stephen P. Robbins - Timothy A. Judge. (2008). Perilaku Organisasi, Buku 2 Edisi 12. Jakarta: Salemba Empat.

Suwanda. (2018). The Influence Ethos Employment and Implication on Dose Performance of Industrial Management Study Program in Kopertis Region III Jakarta Indonesia, International Journal of Business and Applied Social Science (IJBASS), Vol. 4 Issue 5 pp. 58-71

Syamsuddin. (2006). “Analisis Pengaruh Karakteristik Individu Terhadap Perilaku Kepemimpinan, Kinerja Bawahan dan Pertumbuhan Usaha: Studi Kasus Taylor.

Timpe. A.D. (1992). Seni Manajemen, Manajemen Sumber Daya Manusia, Kinerja. Jakarta: LPM.

Veitzhal Rivai. (2011). Manajemen Sumber Daya Manusia untuk Perusahaan: Dari Teori ke Praktek. Ed. 2-cet. 4. Jakarta; Rajawali Pers.

W.D. McCausland, K. Pouliakas \& I. Theodossiou. (2005). "Some are punished and some are rewarded", International Journal of Manpower, 26 (7/8), pp. 636-659 
Hazritanto et al., Journal of Technical Education and Training Vol. 11 No. 1 (2019) p. 151-158

Wibowo. (2011). Manajemen Kinerja (3rd ed.). Jakarta: Rajawali Pers.

Wibowo. (2011). Manajemen Kinerja: Ed. 3-cet. 5. Jakarta: PT Raja Grafindo Persada. 